\title{
The Effectiveness of Project Based Learning to Improve Students' Report Writing
}

\author{
Yusri $^{1, *}$ Sri Gustiani ${ }^{1}$ Tiur Simanjuntak $^{1}$ Evi Agustinasari ${ }^{1}$
}

\author{
${ }^{1}$ English Department, State Polytechnic of Sriwijaya \\ *Corresponding author. Email: yusri@polsri.ac.id
}

\begin{abstract}
The aim of this study is to find out whether or not project based learning is effective to improve students' writing on project report to the students at English Department, Sriwijaya state Polytechnics. This research applied a quantitative approach. In principle, experimental research was conducted to examine the effect of the treatment that has been given to something. It involved three independent variables, namely the Project based learning (X1), GWP (X2) and the dependent variable is writing a project report $(\mathrm{Y})$. The samples were assigned to put their ideas into pragraphs as a means to collect the data. It was obtained that the scores of the students' writing skills with the approaches project based learning and guided writing procedure were 78 dan 73 respectively. It was no doubt that the students' writing skills with Project based learning was better compared with the approach of guided writing procedure.
\end{abstract}

Keywords: Project Based Learning, Project Report.

\section{INTRODUCTION}

Good writing skills play an important role in academic success, whether it is writing assignments, reports, or proposals. Writing is a manifestation of listening, speaking and reading skills. Writing skills are very important because this shows one's ability to express ideas, thoughts, knowledge, and experience as a productive skill. According to McWhorter [1] many things are gained by having writing skill: (1) writing skill helps people in studies and careers, (2) It trains students learn and remember things, (3) It encourages students think more clearly, and (4) It strengthens students' problems skill. Furthermore, Langan [2] said that there are three benefits gained by writing. First, writing helps one become a better writer, for example it can be applied when writing exams, writing reports, and writing scientific. Second, discipline in writing will improve the ability as a reader and a listener. And third, writing makes a good thinker. In the world, the ability to write should be owned by every student. If they are avid writers, they will have ability to express ideas on papers. In reality they still have problems to express their ideas. Pilot study was conducted in 2019 at English Department, State Polytechnic Sriwijaya Palembang to explore students' report writing ability. It was found out that they still have difficulties in writing the final project. The first problem dealed with the content of the report. It is not coherent and the lack of strong arguments written so it is very difficult to convince the readers. This finding is also supported by research done by Evi [3]. They found out that students' report writing related to aspects of language such as: mastery of English vocabulary, choice of words or diction, use of correct grammar, skills to arrange paragraphs into a writing that has cohesion and coherence. The same problem was found that most students' English essays are less organized, awkward grammar, without sentence structure, and weak in the use of vocabulary.

The writers assumed that one of the causes of the problems is teacher's strategy in teaching report writing. In this study, the writers applied PBL in teaching writing to improve the ability to make English reports. Project Based Learning is a learning method that uses problems as a first step in gathering and integrating new knowledge based on experience in real activities. Project Based Learning requires a comprehensive teaching approach where student learning environments are designed so that students can investigate authentic issues including deepening the material of a subject topic, and carrying out other meaningful assignments. This approach allows students to work independently in constructing them in tangible products as it is stated by Habulembe and Smith [4]. In Project Based Learning, students are given a task or a complex project, quite difficult, complete, but realistic and then given enough 
assistance so that they can complete the task. In addition, the application of Project Based Learning encourages the growth of Nurturant competencies such as creativity, independence, responsibility, confidence, and critical and analytical thinking. Gokhan [5] stated that Project Based Learning has great potential to provide a more interesting and meaningful learning experience for students.

\section{LITERATURE REVIEW}

\subsection{The Concepts of Writing Skills}

Experts have their own opinions about understanding skills. According to Winterton and Srtingfellow [6] skill is something that refers to the level of ability, in terms of accuracy and speed in doing a particular task related to psychomotor abilities and mental cognitive abilities. Furthermore, Green [7] argues that skills are something that tends to refer to the professional dimension, skills that are manipulated, knowledge related to the process of technical work.

Writing should be possesed by English language students. In all aspects of life, personal, in school and in business, it is very important to use for communication as stated by McClelland and Marcotte [8]. According to Gebhard [9]It is very closely related to the choice of words, grammar (the suitability of the subject with the predicate, tensis, and use of articles) syntactically and mechanically. Furthermore, it is said Byrne [10]that writing is activity to express ideas into sentences to make coherent and cohesive. In other words the writer translates their thoughts into written form. And the writing can be understood by the reader.

Raimes [11] stated that writing is a way to express opinions by using the correct choice of words and grammar to communicate with readers in writing. It is also a process when the writer thinks of something and the opinion is expressed in written form. There are five stages in the writing process namely; pre-writing, drafting, revising, editing and publishing. It is the process of planning what will be written, making a draft, reviewing and correcting what has been written so that the final result of the writing so that our writing can be understood by the reader as it stated by Harmer [12]. Based on several opinions, it can be stated that writing skills are the ability to express ideas, ideas, feelings in the form of written language with correct language rules so that other people who read can understand the contents of the writing well.

\subsection{The Concepts of Project Based Learning}

Thomas [13] stated (PBL is a strategy that regulates activities through tasks. When it is applied, an assignment is a hard duty, based on a problem or challenging question, which engages students in design, problem solving, decision making, or inquiry activities; allow students to work in team. It is a comprehensive approach to the learning process that is structured to direct students to investigate real problems as it is stated by Phyllis, Blumenfeld, Elliot Soloway, Ronald Marx, Joseph S. Krajcik, Mark Guzdial, and Palincsar [14]. Gokhan [5] argued that It is a student-centered learning mode., this strategy student have opportunities to arrange, apply and assess to counter the problems.

It consists of the way how students report the project of the investigation and the solution of the problems through presentation according to Arends [15]. Alan and Stoller [16] stated that the learning process that maximizes language, content, meaningful learning, which requires the responsibilities of the instructors to apply the tasks challenged. PBL groups students into groups to investigate the problems task and attempt to solve the problems. It integrates language and content of language learning goals.

From the explanation above we concluded that the PBL assigned students to put their ideas into persuasive essays into three ways namely: describing problems, identifying problems and proposing solutions to these problems that are accompanied by examples so that they are able to persuade and influence readers in writing to do what the author or writer wants. There are some advantages of Project Based Learning

According to Alan and Stoller [16], there are some advantages of project based learning. They are as follows: (a). Increasing motivation, (b). Improving the ability of research, (c). Increasing collaboration. And (d). Improving resource management skills.

\subsection{Report Writing}

Report is a form of conveying information both orally and in writing. The report is based on a task or project that was undertaken. Project reports containing information obtained from investigations. The content of the report contains information about: problems, causes of problems, impact of problems and solutions to these problems. Students need accurate data to prove the results of their projects. In order to make the writing report easier, research and data testing were conducted earlier. Later this data will be very useful for writing on a work. This report is very useful to test your accuracy and understanding of the material created.

\section{RESEARCH AND METHODOLOGY}

\subsection{Method of Research}

This research applied a quantitative approach. In principle, experimental research was conducted to examine the effect of the treatment that has been given to something. Cresswell [17] also said that the experimental method is a research method used to look for the effect of certain treatments on others under controlled conditions. This research involves three 
independent variables, namely the Project based learning (X1), GWP(X2) The dependent variable is writing a project report (Y). The experiment was done to the students of English Department in the academic year 2019/2020. The students were treated for 18 meetings. Two meetings were used to do the pretest and post test. The experimental class was taught via PBL and the control class was applying GWP.

This research was conducted in semester 6, Writing 4 subject, English Department of state Polytechnic of Sriwijaya Palembang. Project based learning provided them how to write essay as argumentative and persuasive writing. The research was conducted in the odd semester of February-July 2020. The population of this research Subjects was all the semester 6 students of English department. The total is 84 students. The sampling technique used simple random sampling.

\subsection{Techniques of Collecting and Analyzing Data}

To collect the data, the researcher gave pre test and post test. To assess students' report writing before treatment, pre test was conducted. To know the impact of the strategies, the students were given post test; it was given after the treatment. Writing essay was used as proposed by Brown [18] which functioned to know the impact of the strategies applied as stated by Savage \& Shafiei [19].

In analyzing the data obtained from the tests, the researchers divided the scores of students into two groups, the experimental group and the control group. Test results are presented in descriptive form and also from t-test. The researcher calculates the difference; pretest and posttest in the experimental and control group. If the value of t-obtained is higher than the value of freedom. This means that the research hypothesis "there is a statistically significant difference in students' report writing before and after being taught through the Project based learning. If the statistical value is lower than the t-table value, it means that the null hypothesis "There is no statistically significant difference in students' report writing before and after being taught project based learning is rejected. Data are analyzed using (SPSS).

\section{FINDINGS AND DISCUSSIONS}

\subsection{The Ability of the Students' Report Writing in the Experimental Group}

Expressing ideas coherencely and cohesively in written is an essential comtence owned by English learners, as at the end of their studies they have to write report projects. One of the characteristics of report project is the ability to persuade readers. In order to persuade them, the writers have to have strong arguments. The arguments should be supported by main ideas supporting details and examples. The project based learning can be one of the alternative strategies to strengthen students' report writing skill, confidence and motivation in writing. Before treating sampe students via PBL, the writers gave them pre test. The purpose is to diagnose their report writing skill before being taught through PBL.

The average score in the pre-test that the students reached was 7.3. The writers found that the lowest score was 6.9 reached by one student and the highest score was 8.4 reached by one student as well. See graph 1 .

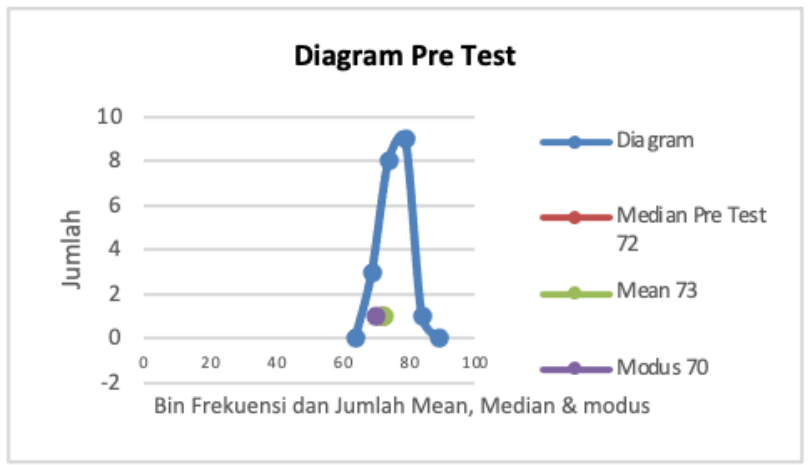

Figure 1 The Diagram of the Pre Test of the Experimental Group

After taking the pre-test, the students were introduced with teaching report writing by using Project based learning (PBL). After treating that, the writers gave the post-test to the students, which aimed at knowing the students' progress in learning report writing via PBL. In this test, the average score in the post-test that the students reached was 7.8 , the lowest score was 70 reached by one student and the highest score was 8.5 obtained by one student. Graph 2 shows the improvement of the srudents' wrtiting after treatment.

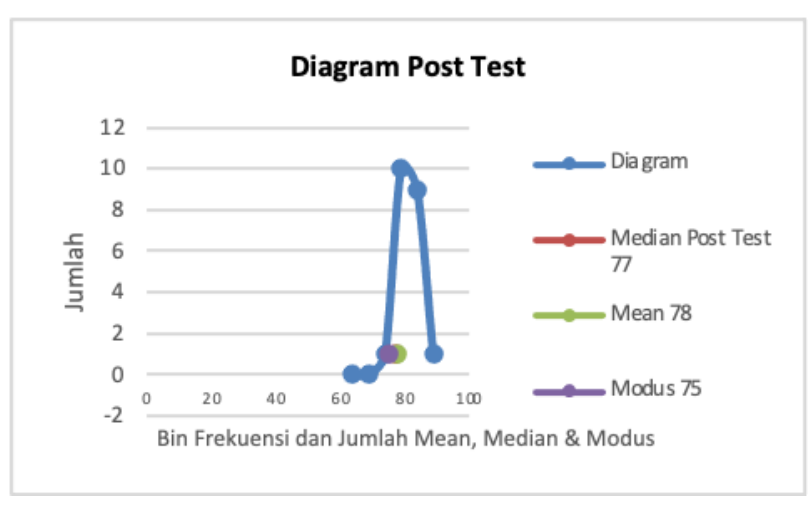

Figure 2 The Diagram of the Post Test of the Experimental Group

\subsection{The Ability of the Students' Report Writing of the Control Group}

Expressing ideas coherencely and cohesively in written an essential comtence owned by English 
learners, as at the end of their studies they have to write report projects. One of the characteristics of report project is the ability to persuade readers. In order to persuade them, the writers have to have strong arguments. The arguments should be supported by main ideas supporting details and examples. The project based learning can be one of the alternative strategies to strengthen students' report writing skill, confidence and motivation in writing. Before treating sampe students via Guided writing procedure, the writers gave them pre test. The purpose is to diagnose their report writing skill before being taught through GWP.

In the pretest, the average score in the pre-test that the students reached was 7.1. The writer found that the lowest score was 6.5 reached by two students and the highest score was 7.7 reached by one student as well . See Graph 3.

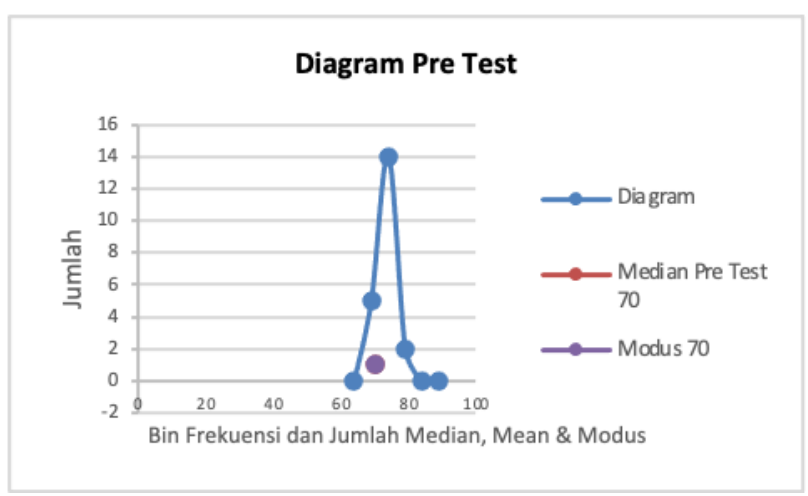

Figure 3 Diagram of Pre Test of the Control Group

After taking the pre-test, the students were introduced with teaching report writing by using Guided writing procedure (GWP). After treating that, the writers gave the post-test to the students, which aimed at knowing the students' progress in learning report writing via GWP. In this test, the average score in the post-test that the students reached was 7.4 , the lowest score was 70 reached by five students and the highest score was 8.0 obtained by two students. See Graph 4 .

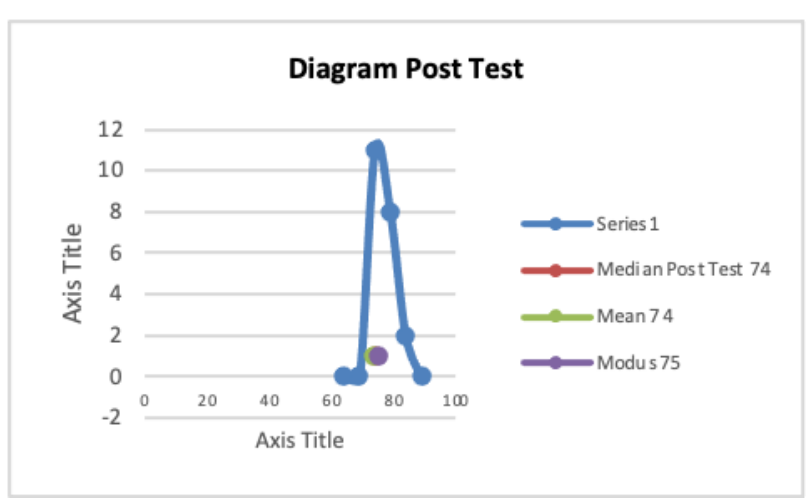

Figure 4 Diagram of Post Test of the Control Group

\subsection{Discussion}

It was obtained that the ability of students' taught a project based learning and guided writing procedure were 78 dan 73 respectively. It was no doubt that the students' writing skills with Project based learning was better compared with the approach of guided writing procedure. First, the superiority of the project based learning model is in accordance with what Stoller and Allan said that [16] he assignment given by the lecturer to find solutions to problems in learning to write makes students active in digging up information, analyzing the information and reporting it and the impact of activities. This is the knowledge and mastery of language skills, especially persuasive writing skills in English because when students are looking for solutions to problems they have to express strong ideas that they are able to persuade and influence written readers to do something the author or writer wants.

Second, in line with Stoller and Allan, Hunt and Beglar [20] also say that a task is an activity carried out by learners using available language resources and has an impact on tangible results, for example; solve problems or share or compare experiences. When working on tasks, learners carry out various activities such as: negotiating meaning, paraphrasing, conducting experiments that have an impact on good language development because in persuasive writing skills they must have the ability to arrange words or sentences into a good text, the ability to choose the right words to develop and show ideas as well as being able to use grammar well and being able to use spelling and punctuation correctly and indirectly improving students persuasive writing skills in English.

Third, by engaging students with real-life tasks, engaging activities is an excellent strategy for integrating the four language skills, namely listening, speaking, reading and writing skills. Students must carry out authentic investigations that seek real solutions to real problem. When students feel that they are engaged in a task that actually contributes to solving the problem, they will become more involved in the writing process, especially persuasive writing in English. This result is the same as the research conducted by Natela Doghonadze and Guknara Gorgiladze [21], namely that the final average score of students is higher than the initial score of students after applying the project-based learning model compared to the average score of children taught by conventional learning models. The results of this study recommend a project based learning model to be applied in learning, especially in learning to write in writing reports in English.

\section{CONCLUSIONS}

The superiority of the project based learning model compared to the Guided writing procedure learning model is that in the project based learning model the benefits of the assignments given by the lecturer to find solutions to problems in learning to write make students active in digging up information, analyzing the information and reporting it and the impact on it. This activity is the knowledge and mastery of language skills, especially persuasive writing skills in English because when students are looking for problem solutions they 
have to express ideas, ideas, experiences, illustrations, facts, opinions, arguments, reasons, which are reasonable, logical and strong which is accompanied by examples so that they are able to persuade and influence written readers to do something the author or writer wants.

Assignments are activities carried out by learners using available language resources and have an impact on tangible results, for example; solve problems or share or compare experiences. When working on tasks, learners carry out various activities such as: negotiating meaning, paraphrasing, conducting experiments that have an impact on good language development because in persuasive writing skills they must have the ability to arrange words or sentences into a good text, the ability to choose the right words to develop and show ideas as well as being able to use good grammar and being able to use spelling and punctuation correctly and indirectly improving students' report writing skills in English.

\section{REFERENCES}

[1] McWhorter T Kathleen. Successful in College Writing: Skills Strategies Learning Styles. Fifth Edition. Boston. MA, 2012.

[2] Langan John. College Writing Skills with Readings. McGraw Hill: Singapore, 2008.

[3] Agustina Sari, E., Gustiani, S., Yusri, \& Simanjuntak, T. (2018). Teaching writing to the English Department Students of Sriwijaya State Polytechnics through a Process Genre Model Approach. Journal of English in Academic and Professional Communication JEAPCo. 5(2), 43-56.

[4] Habulembe, Smith H. 2007. A Classroom Response to HIV/AIDS-Project Proposal Writing. English Teaching Forum, 45 (1), 2007.

[5] Bas Gokhan. Investigating the Effects of Project Based Learning on Students' Academic Achievement and Attitudes towards English Lesson. TOJNED. The Online Journal of New Horizons in Education-October, volume 1, issue 4, 2011.

[6] Winterton Jonathan and Stringfellow Emma. Typology of Knowledge Skills and Competences: Clarification of the Concept and Prototype. Office for Official Publication of the European Communities: Luxembourg, 2006.

[7] Green Francis. What is Skill. An Inter-Disciplinary Synthesis. LLAKES: London, 2011.
[8] Marcotte Hale Patricia and McClelland. Writing Matters: Introduction to Writing and Grammar. McGraw-Hill Education (Asia): Singapore, 2007.

[9] Gebhard G. Jerry. Writing and Probem Solving: Teaching English as a Foreign Language or Second Language: A Teacher Self Development and Methodology Guide.The University of Michigan: United States of America, 2000.

[10] Byrne, Donn. Teaching Writing Skills. Longman: New York, 1993.

[11] Raimes Ann.Technique in Teaching Writing. Oxford University Press: New York, NY. 2010.

[12] Harmer, Jeremy. How to Teach English. Pearson Education Limited: England. Longman, 2011.

[13] Thomas, W. John. A Review of Research on Project -Based Learning. California: The Autodesks Foundation 111 Melnnis Parkway, 2000 .

[14] Krajcik, Marx, Ronald, Soloway Blumenfeld and Phyllis. Motivating Project Based Learning:Sustaining the Doing, Supporting the Learning. Educational Psychologist, 26 (3\&4), 369-398, 2005.

[15] Arends, R.I. Learning to Teach, 9th ed. Boston: McGraw Hill Company Inc, 2012.

[16] Stoller L and Allan B. 2005. Maximizing the Benefits of the Project Work in Foreign Language Classrooms. English Teaching Forum. 43 (4), 2005.

[17] Cresswell, John W. Educational Research 4th edition, New York, Pearson, 2012.

[18] Brown, H.D. Teaching by principles: An interactive approach to language pedagogy. Englewood Cliffs, NJ: Prentice Hall Regents, 2013.

[19] Savage, A., \& Mayer, P. (2005). Effective Academic Writing Book 2-The short essays. England, UK: Oxford Press.

[20] Hunt Alan and Beglar David. Edited by Richards and Renandya. Methodology In Language Teaching: An Anthology of Current Practice: Implementing Task Based Language Teaching. Cambridge: Cambridge University Press, 2003.

[21] Doghonadze Natela and Gorhiladze Gulnara. Problem Solving in Teaching Foreign Languages to Students of Pedagogical Departments. IBSU Scientific Journal Vol 2 (1), 2013. 